\title{
ENVIRONMENTAL LIVABILITY'S ASSESSMENT OF IRAQI GOVERNORATES USING A.H.P MODEL AND GEOGRAPHY INFORMATION SYSTEM (GIS)
}

\author{
Mizgeen .M . Hassan and Soleiman .Foroughi \\ Dept of Geography, University of Duhok, Kurdistan Region-Iraq
}

(Received: December 12, 2017; Accepted for Publication: February 26, 2018)

\begin{abstract}
Nowadays Iraq has encountered serious challenges, including war, terrorism, and economic crisis. This problem has seriously reduced the ability of this country to provide a decent life for its citizens and this perfectly highlights the necessity of various aspects of livability. Based on this view, in this research environmental livability is assessed as one of the important aspects of livability. With this purpose in mind, in this paper A.H.P model was used to determine the relative importance of criteria and GIS was used to overlay the layer and to create the environmental livability map. The methodology used in this research is descriptive, comparative, analytical, and field work as well as a questionnaire, and the data used in this research are taken from the statistical book published under the title of Iraqi Household Socio-Economic Survey (IHSES) in 2012. Sample size is 25,488 households. The criteria used are the percentage of households of Iraqi governorates that are affected and are close to the following conditions: 1- smoke and gases, 2- dust, 3- bad odor, 4- noise, 5- garbage and dirt, and 6- stagnant water. The final map classifies the governorates into five classes in terms of livability (relatively unsuitable, unsuitable, strongly unsuitable, very strongly unsuitable, and extremely unsuitable). Achieved weight of A.H.P model shows that garbage and dirt (0.249) and stagnant water (0.221) are the most important criteria. Results obtained from the final maps show the households of Nineveh, Al-Qadisiyah, and Missan governorates to have the worst condition in terms of environmental livability.
\end{abstract}

KEYWORDS: Environmental Livability; IHSES; A.H.P; GIS; Governorate; Iraq

\section{LITERATURE}

Tn its original sense, livability means the ability to have human life. This subject was obtained from ecological sustainability, and solving social and economic problems. Livability or viability in a general sense is linked with some concepts and terms, including sustainability, the quality of life or the quality of place and healthy societies. Livable settlement is the appropriate space to live in and work (Nel \&Goldman, 2006:5). Indicators measuring the viability vary from one country to another, since viability should be evaluated within the specified time and place.
Livability is divided into four interdependent dimensions: economic, social, cultural and environmental (refer to Table 1). Creating a habitable settlement is one of the duties and obligations of planners and city managers. Viability is a new subject that can support planning activities and development. This is necessary for geographers to follow this subject seriously. Secondly, the subject of livability is not limited to urban planners; rather all citizens who live in the city and have civil rights are involved in it (Hankins, 2009:84).

Table(1):-Types of Livability and Vitality of Charles Landry

1-Economic vitality
That is examined with variable levels of
employment, net income, living
standards in the area under study, the
annual number of tourists and retailer
performance and the value of land and
property.

2-Social vitality

That is measured with variable levels and

$\begin{array}{ll}\text { Types of vitality and livability } & \text { Livability means long-term self- } \\ \text { sufficiency, sustainability, } \\ \text { compatibility, adaptability and } \\ \text { rehabilitation, vitality in activity levels, } \\ \text { participation, interaction and } \\ \text { relationship, in the outside word. }\end{array}$
participation, interaction
relationship, in the outside word. 


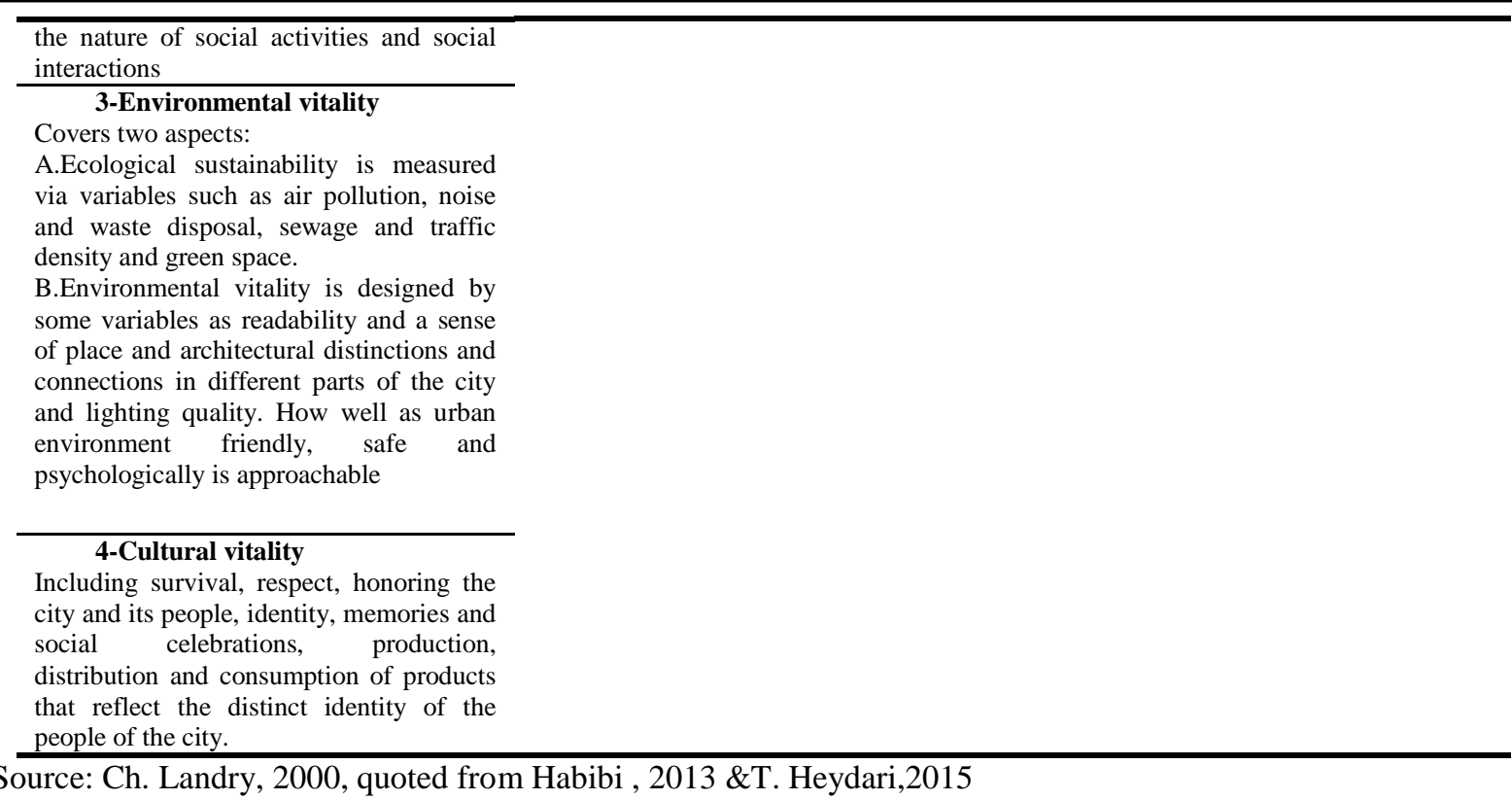

Source: Ch. Landry, 2000, quoted from Habibi , 2013 \&T. Heydari,2015

Environmental livability is one of the important aspects of livability that is targeted health, safety, comfort, beauty, and cleaning of human environment.

\section{MATERIALS AND METHODS}

The study was carried out at the level of Iraqi governorates. Therefore, the statistical society is total population of Iraqi states living across 18 governorates.

Key data were obtained from field survey using questionnaire method, which was conducted by the Central Organization for Statistics and Information Technology (COSIT) and the
Kurdistan Region Statistics Organization (KRSO) in collaboration with World Bank in a project called Iraq Household Socio-Economic Survey (IHSES) in 2012.

Data were collected using sample survey. The IHSES-II (2012) intends to provide estimators of comparable quality for each one of Iraq's 18 governorates. This implies that the sample should be explicitly stratified by Gadah (District). A sample size of 216 households per district is proposed, equivalent to a total sample of 25,488 households for the country (COSIT \& KRSO \& the Word Bank, Iraq Household Socio-Economic survey, second round, p. 3, 2012).

Table( 2):- Sample Size (Households participating IHSES project) of each Governorate

\begin{tabular}{|c|c|c|c|c|c|c|c|c|c|}
\hline Governorate & $\begin{array}{l}\frac{y}{0} \\
\frac{\vec{Z}}{\vec{D}}\end{array}$ & $\begin{array}{l}\bar{\Xi} \\
\stackrel{D}{D} \\
\stackrel{\Xi}{Z}\end{array}$ & 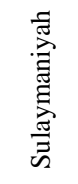 & 兰 & $\begin{array}{l}\overline{7} \\
\text { 站 }\end{array}$ & $\begin{array}{l}\frac{\pi}{\pi} \\
\stackrel{\overbrace{}}{\overparen{A}}\end{array}$ & 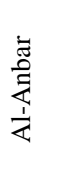 & $\begin{array}{l}\vec{J} \\
\bar{J} \\
\overline{0} \\
\tilde{J} \\
\infty\end{array}$ & $\begin{array}{l}\overline{\overline{0}} \\
\text { 苛 }\end{array}$ \\
\hline $\begin{array}{l}\text { Number of } \\
\text { Households }\end{array}$ & 1348 & 1885 & 3292 & 827 & 1933 & 1272 & 1718 & 2150 & 863 \\
\hline Governorate & 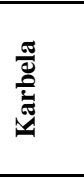 & $\begin{array}{l}\frac{\vec{v}}{5} \\
\frac{5}{3}\end{array}$ & 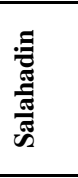 & 离 & 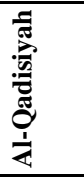 & 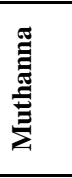 & $\begin{array}{l}\dot{\tilde{\Xi}} \\
\ddot{\bar{\Xi}}\end{array}$ & 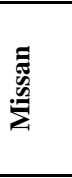 & 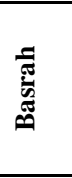 \\
\hline $\begin{array}{l}\text { Number of } \\
\text { Households }\end{array}$ & 612 & 1292 & 1717 & 646 & 858 & 862 & 1078 & 1288 & 1506 \\
\hline
\end{tabular}


Reference: http://microdata.worldbank.org/index.php/catalog/2334/data_dictionary

To perform the analysis, first, IHSES 2012 data was entered into attribute table of Arc GIS10.2 software and they were linked to Iraqi governorate map. In the next step, based on each criteria, governorates were classified into five classes in terms of livability according to experts (Table 4): relatively unsuitable (code 1), unsuitable ( code 3), strongly unsuitable (code 5), very strongly unsuitable (code 7) and extremely unsuitable (code 9). Then, layers were made according to the level of suitability of livability (Map1-6) and were converted into raster format (appropriate format for overlaying). In order to determine the relative importance and weight of criteria, Analytic Hierarchy Process (A.H.P) model was used that consists of two steps: 1 . determining the weight of criteria and 2 . Calculation of consistency ratio $(C R)$ to ensure that the calculated weights are reliable based on A.H.P logic (when $\mathrm{CR}$ < 0.1 is acceptable). In this research, $\mathrm{CR}$ is 0.02 . In the last step, layers are combined with raster overlay tools in Arc GIS10.2 to make the final map of environmental livability (Map 8). The following flowchart shows the steps of study.

Flow chart1: The Process of Research

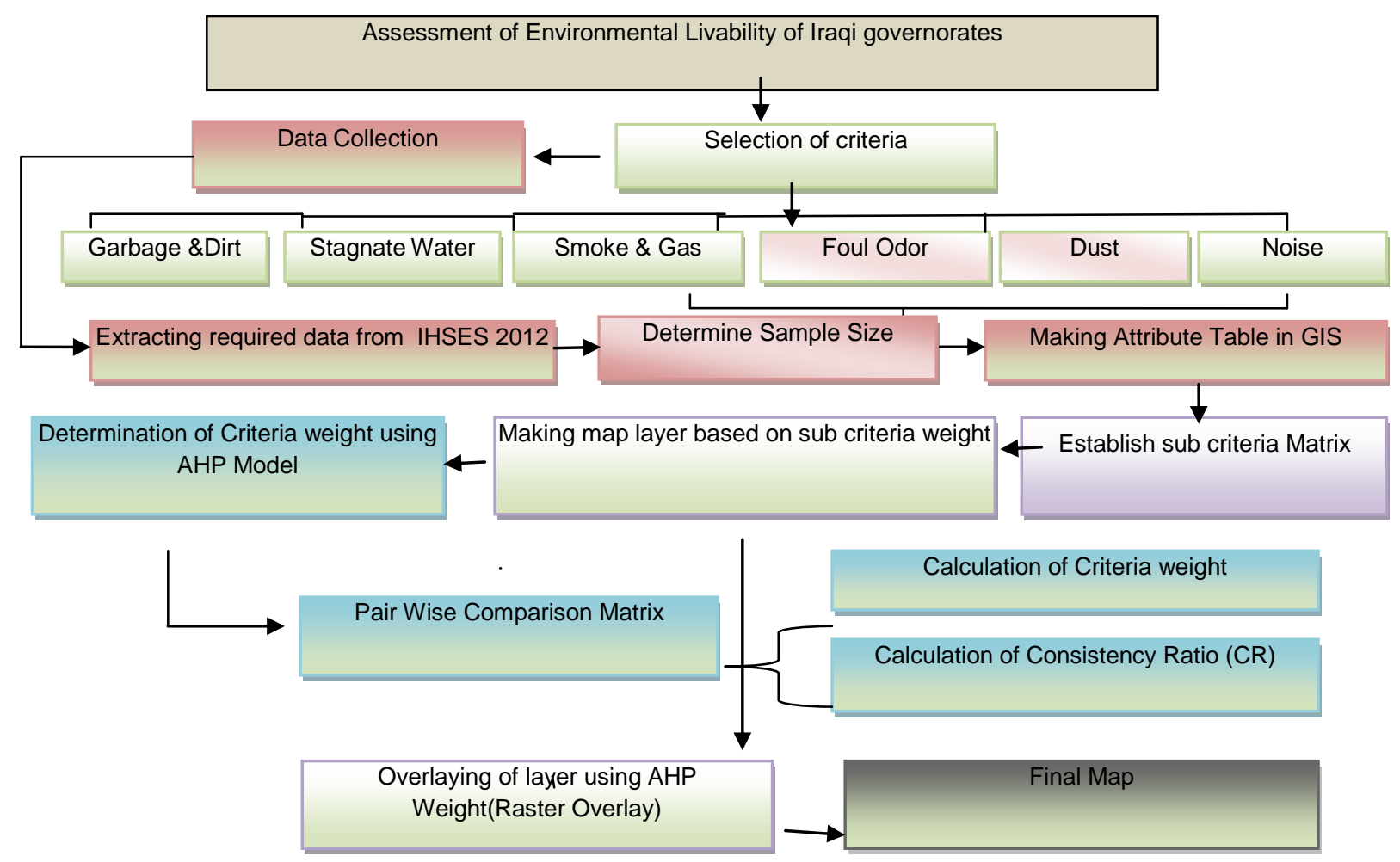

Reference: design of authors 
Journal of University of Duhok., Vol. 21, No.1 (Humanities. and Social. Sciences),Pp 401-410, 2018

DOI: https://doi.org/10.26682/hjuod.2018.21.1.21

Table(3):- Percent of Household affected by Unsuitable Environmental Conditions

\begin{tabular}{lcccccc}
\hline \multicolumn{1}{c}{ Governorate } & $\begin{array}{c}\text { Smoke } \\
\text { \&Gases }\end{array}$ & Dust & Bad Odor & Noise & Garbage & Stagnant Water \\
\hline Duhok & 10.1 & 38.8 & 28.9 & 18.3 & 14.7 & 16.2 \\
\hline Ninevah & 12.1 & 48.9 & 26.9 & 14.9 & 43.3 & 44.4 \\
\hline Sulaimaniya & 3.6 & 26.2 & 13.0 & 5.9 & 8.0 & 6.3 \\
\hline Kirkuk & 2.1 & 20.7 & 8.6 & 2.3 & 14.8 & 34.5 \\
\hline Erbil & 12.3 & 27.9 & 20.8 & 12.1 & 16.0 & 11.6 \\
\hline Diala & 7.0 & 25.7 & 10.8 & 7.8 & 12.7 & 27.9 \\
\hline AL-Anbar & 1.8 & 21.4 & 9.4 & 4.0 & 14.1 & 17.2 \\
\hline Baghdad & 8.3 & 17.9 & 19.9 & 13.1 & 21.9 & 28.5 \\
\hline Babil & 7.3 & 34.6 & 16.0 & 9.8 & 15.2 & 40.8 \\
\hline Kerbela & 2.6 & 6.4 & 8.3 & 4.7 & 12.4 & 14.9 \\
\hline Wasit & 8.9 & 23.6 & 12.8 & 4.3 & 15.6 & 22.0 \\
\hline Salahadin & 9.4 & 27.7 & 14.6 & 10.3 & 16.1 & 21.0 \\
\hline AL-Najaf & 1.4 & 3.3 & 1.2 & 1.1 & 3.1 & 7.9 \\
\hline AL-Qadisiya & 4.5 & 20.6 & 36.2 & 10.1 & 30.4 & 55.9 \\
\hline AL-Muthanna & 1.4 & 1.3 & 0.2 & 0.6 & 1.0 & 2.2 \\
\hline Thi Qar & 9.6 & 13.1 & 20.0 & 5.8 & 28.4 & 39.2 \\
\hline Missan & 9.9 & 20.3 & 27.4 & 17.4 & 33.8 & 43.0 \\
\hline Basrah & 7.2 & 17.1 & 15.4 & 7.3 & 14.3 & 26.6 \\
\hline Iraq & 7.1 & 24.2 & 16.9 & 9.0 & 18.0 & 24.1 \\
\hline
\end{tabular}

Reference: http://microdata.worldbank.org/index.php/catalog/2334/data_dictionary

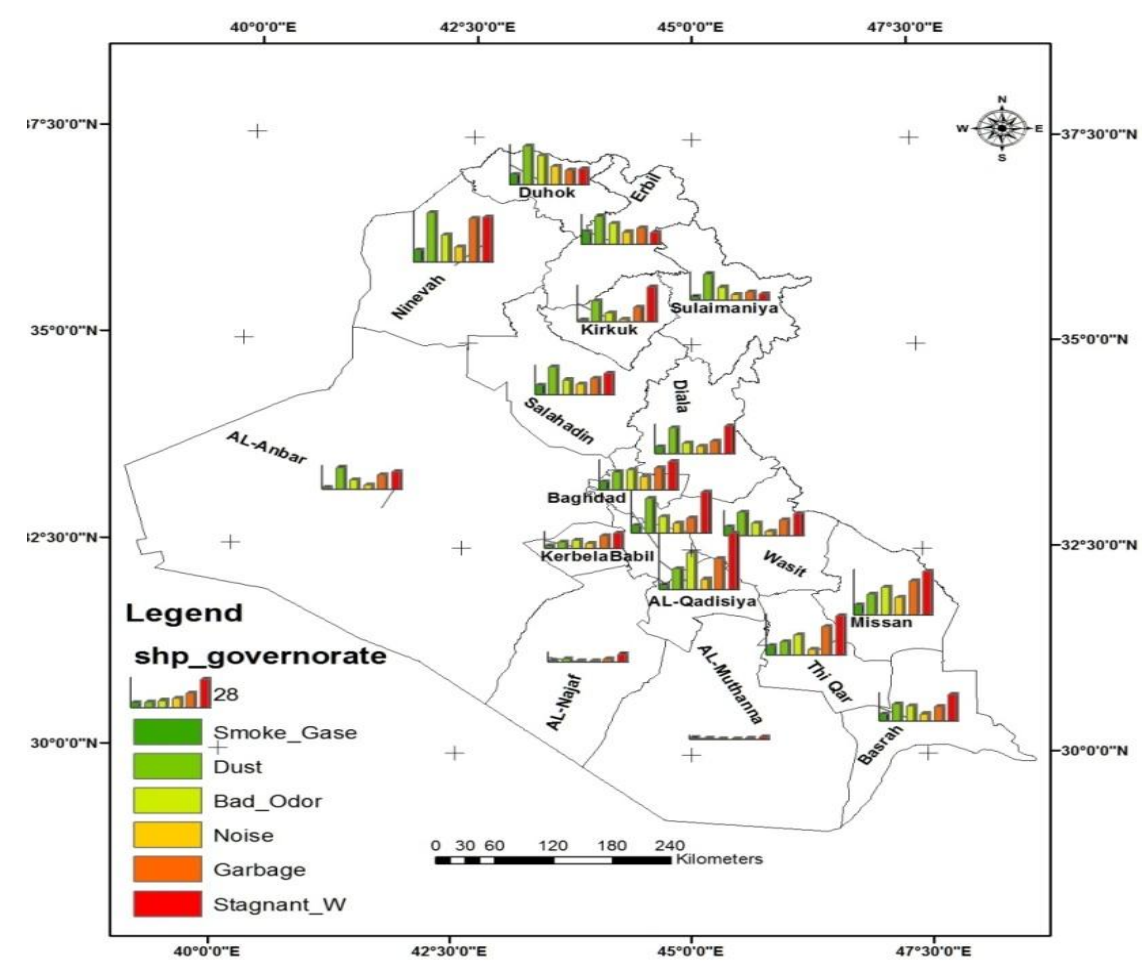


Map7: Choropleth Map of Comparison of Iraqi Governorate based of Environmental Criteria

\section{RESULTS}

As mentioned in this article, IHSES2012 data have been evaluated to classify Iraqi governorates based on unfavorable environmental criteria. Maps based on each criterion show different results as: In terms of garbage and dirt, Nineveh is in extremely unsuitable class and Missan and AlQadisiyah are very strongly unsuitable; Sulaymaniyah, Najaf and Al-Mothana are in the best conditions among Iraqi governorates (Map1). The map of people influenced by stagnant water shows that Nineveh, Babil, Missan, and AlQadisiyah are in the most difficult situation (Map 2).

The map of people influenced by stagnant water shows that Nineveh, Babil, Missan, and Al-
Qadisiyah are in the most difficult situation (Map $2)$. In terms of bad odor criteria, west and southwest governorates are better than others are. Al- Qadisiyah is the worst (Map 3). The map of governorates influenced by smoke and gas shows that Nineveh, Duhok, and Erbil are strongly unsuitable. The reason may be the establishment of oil refineries and gas industries as well as war. Other provinces are relatively unsuitable (Map 4). The map of effectiveness from garbage shows that Nineveh is in the worst conditions. In general, the Southern provinces are better than central and Northern provinces are (Map 5). The map of noise shows that Nineveh, Duhok, Salahadin, Erbil, Bagdad, and Missan are strongly unsuitable. Other governorates are in relatively unsuitable (Map 6).

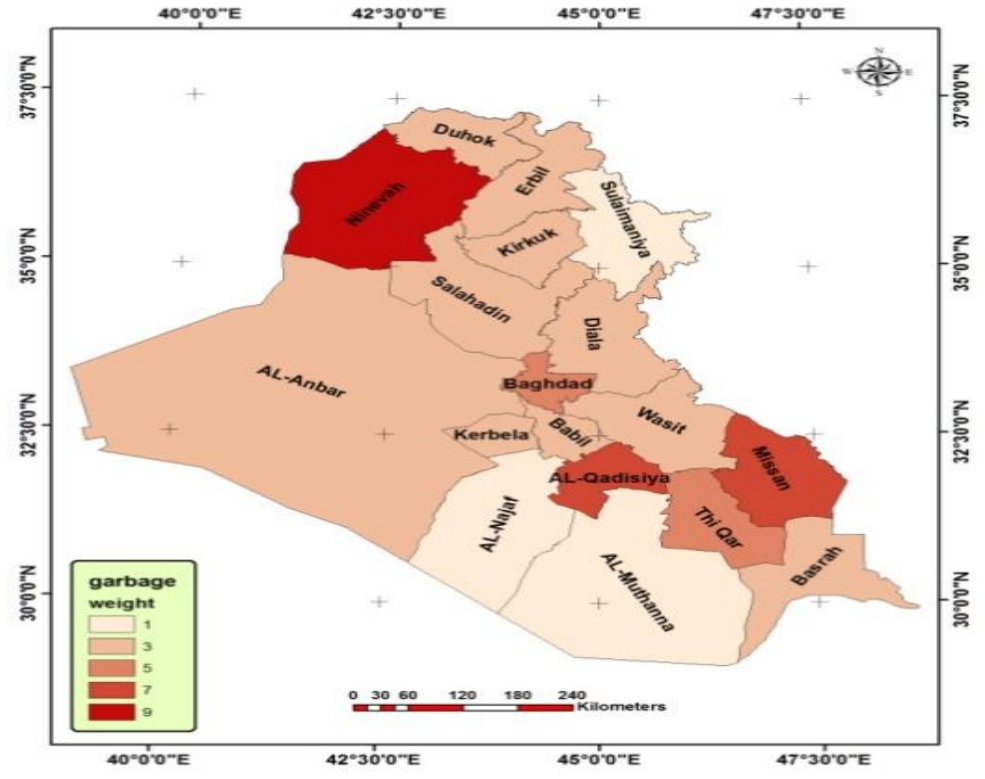

Map1:Environmental Livability of Iraqi Governorate according Garbage and Dirt 


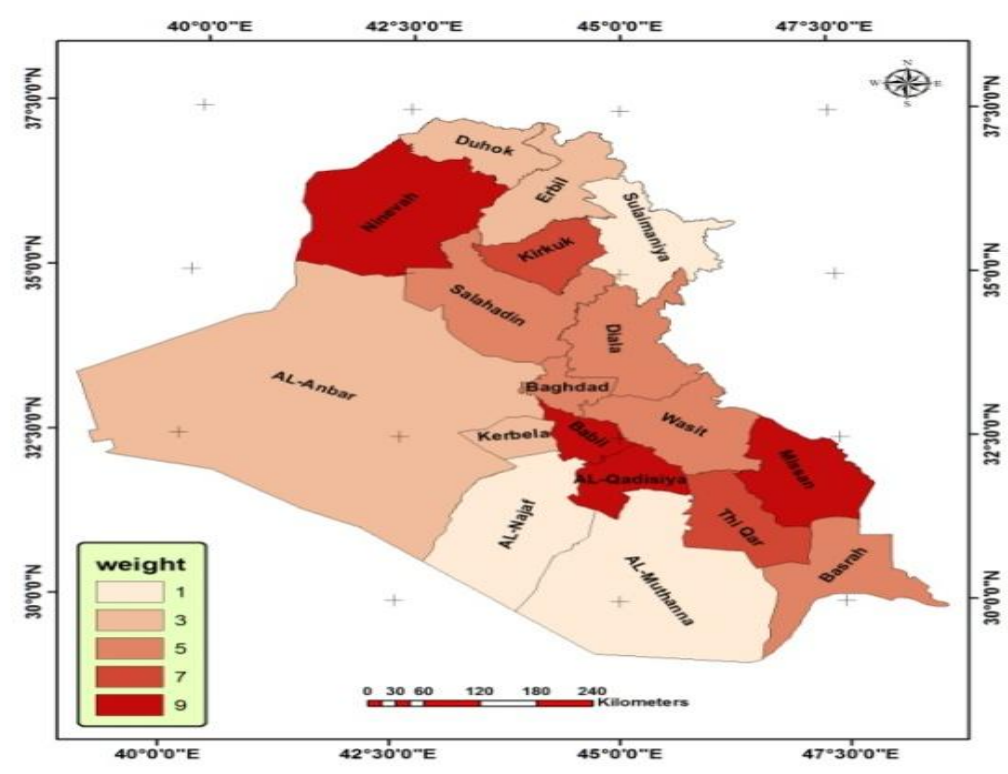

Map(2):-Environmental Livability of Iraqi Governorate according stagnant water

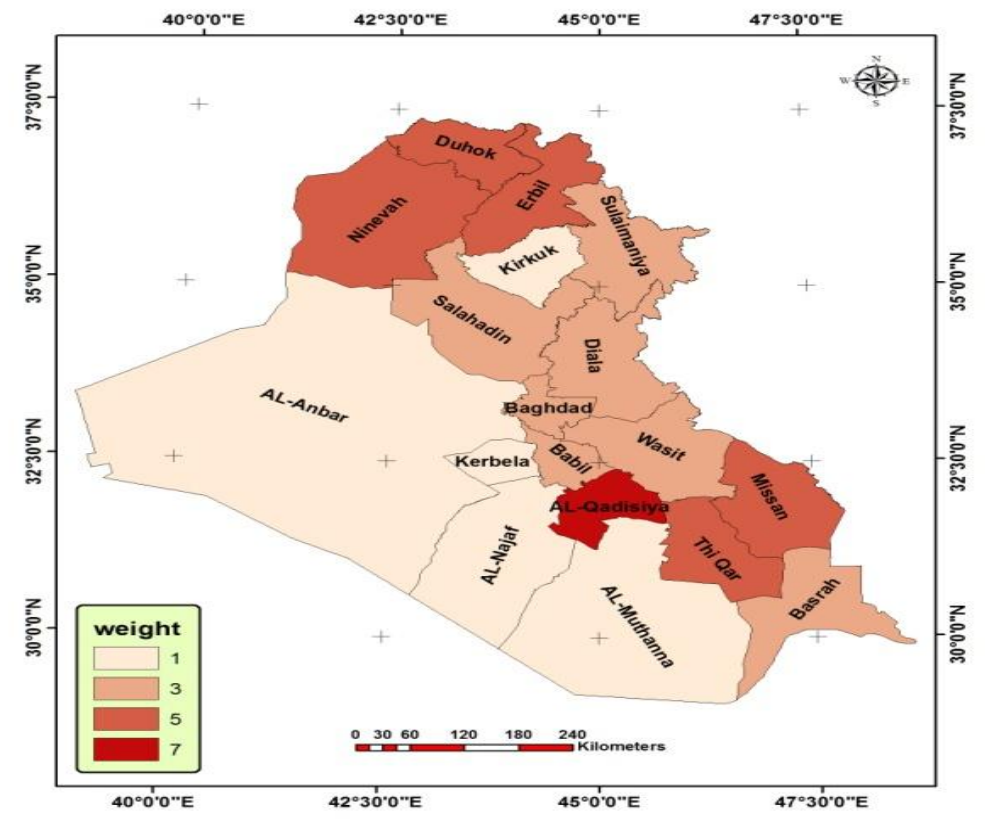

Map3:Environmental Livability of Iraqi Livability of Iraqi Governorate according Bad Odor Smoke and Gases 


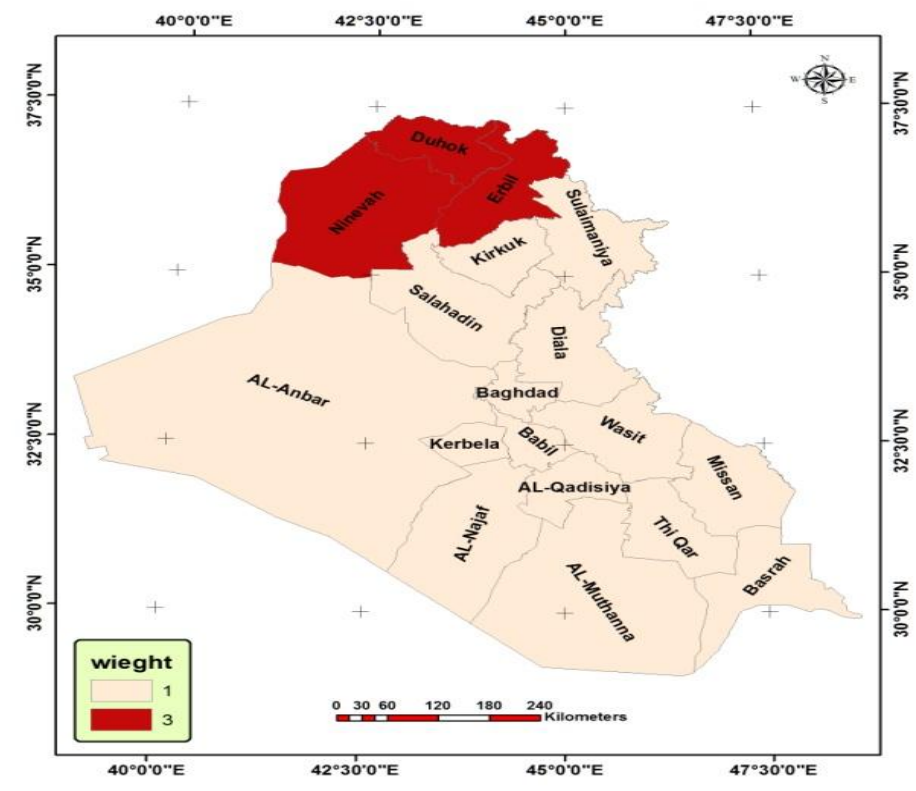

4:Environmental Governorate according

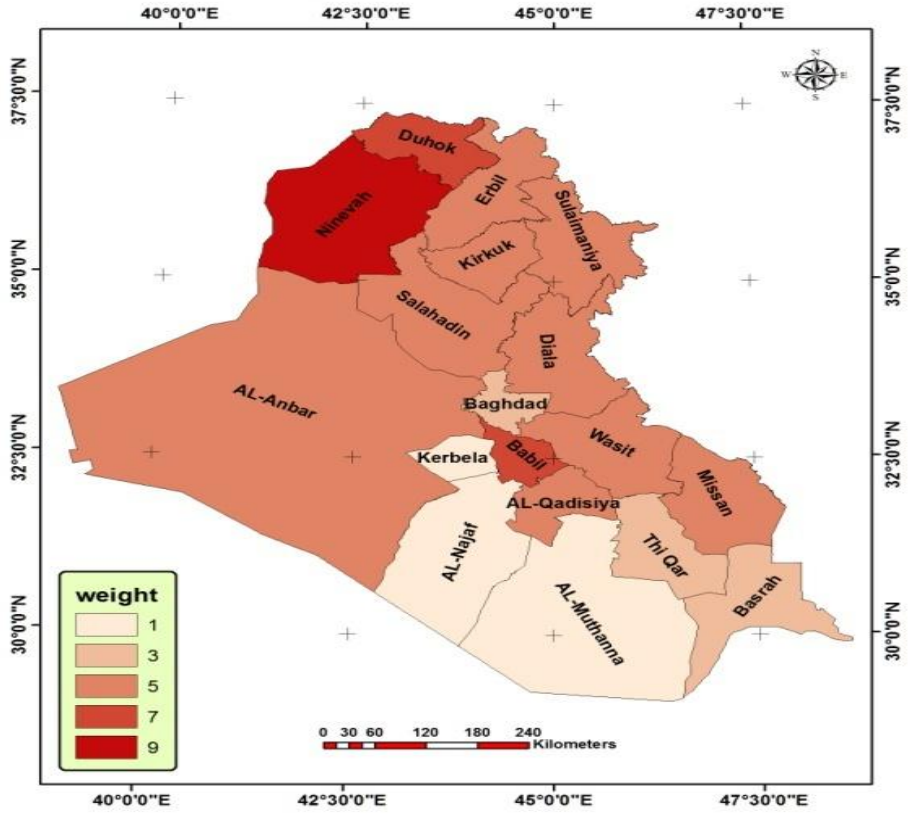

Map5:Environmental Livability of Iraqi Governorate according Dust 


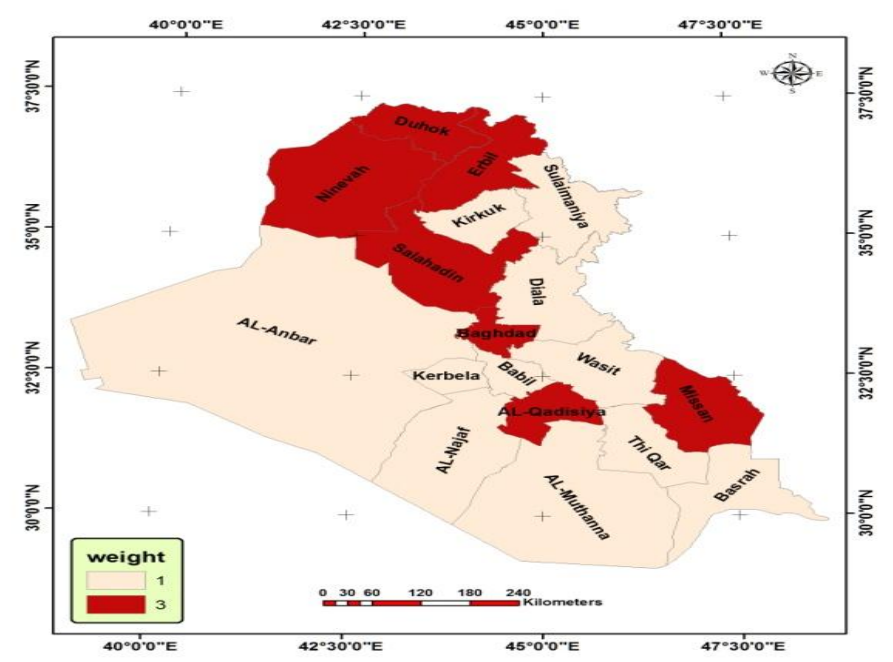

Map6:Environmental Livability of Iraqi Governorate according Noise

Reference: The authors draw based on IHSES2012 data and ArcGIS10.2 software and AHP model

Table(4): -Sub criteria Matrix

\begin{tabular}{|c|c|c|c|c|c|c|c|}
\hline Criteria & Criteria & AHP Weight & $\begin{array}{l}\text { Relatively } \\
\text { Unsuitable }\end{array}$ & Unsuitable & $\begin{array}{c}\text { Strong } \\
\text { Unsuitable }\end{array}$ & $\begin{array}{l}\text { Very Strong } \\
\text { Unsuitable }\end{array}$ & $\begin{array}{c}\text { Extreme } \\
\text { Unsuitable }\end{array}$ \\
\hline \multirow{6}{*}{$\begin{array}{l}\text { Garbage } \\
\text { \&Dirt }\end{array}$} & \multirow{6}{*}{$\begin{array}{r}\text { Garbage } \\
\text { \&Dirt }\end{array}$} & & 1 & 3 & 5 & 7 & 9 \\
\hline & & $0-10 \%$ & * & & & & \\
\hline & & $10.1-20 \%$ & & * & & & \\
\hline & & $20.1-30 \%$ & & & * & & \\
\hline & & $30.1-40 \%$ & & & & * & \\
\hline & & More than $40.1 \%$ & & & & & * \\
\hline \multirow{5}{*}{$\begin{array}{c}\text { Stagnate } \\
\text { Water }\end{array}$} & Smoke \& & $0-10 \%$ & * & & & & \\
\hline & Gas & $10.1-20 \%$ & & * & & & \\
\hline & & $20.1-30 \%$ & & & * & & \\
\hline & & $30.1-40 \%$ & & & & * & \\
\hline & & More than $40.1 \%$ & & & & & * \\
\hline \multirow{5}{*}{$\begin{array}{l}\text { Smoke } \\
\& \text { Gas }\end{array}$} & Foul Odor & $0-10 \%$ & * & & & & \\
\hline & & $10.1-20 \%$ & & * & & & \\
\hline & & $20.1-30 \%$ & & & * & & \\
\hline & & $30.1-40 \%$ & & & & * & \\
\hline & & More than $40.1 \%$ & & & & & * \\
\hline Foul & Dust & $0-10 \%$ & * & & & & \\
\hline \multirow[t]{4}{*}{ Odor } & & $10.1-20 \%$ & & * & & & \\
\hline & & $20.1-30 \%$ & & & * & & \\
\hline & & $30.1-40 \%$ & & & & * & \\
\hline & & More than $40.1 \%$ & & & & & * \\
\hline \multirow[t]{5}{*}{ Dust } & Noise & $0-10 \%$ & * & & & & \\
\hline & & $10.1-20 \%$ & & * & & & \\
\hline & & $20.1-30 \%$ & & & * & & \\
\hline & & $30.1-40 \%$ & & & & * & \\
\hline & & More than $40.1 \%$ & & & & & * \\
\hline \multirow[t]{5}{*}{ Noise } & Smoke \& & $0-10 \%$ & * & & & & \\
\hline & Gas & $10.1-20 \%$ & & * & & & \\
\hline & & $20.1-30 \%$ & & & * & & \\
\hline & & $30.1-40 \%$ & & & & $*$ & \\
\hline & & More than $40.1 \%$ & & & & & $*$ \\
\hline
\end{tabular}

Reference: calculation of Authors 
Results matching Analytic Hierarchy Model (A.H.P) on the criteria show that garbage and dirt (0.249) are the most important criteria, stagnant water $(0.221)$ is in the second rank, calculated weights for other criteria are: smoke and gases
(0.176), foul odor (0.140), dust (0.124), and noise (0.08) (Table 5). In the next step, to ensure that the obtained weights are acceptable, Consistency Ratio (CR) was calculated. The value of 0.02 was confirmed.

Table(5):- matrix of pair wise comparison of the evaluation criterions

\begin{tabular}{|c|c|c|c|c|c|c|c|c|c|}
\hline 西 & $\begin{array}{l}\text { 흠 } \\
\text { Oㅁ } \\
\text { 운 }\end{array}$ & 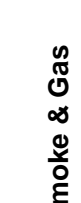 & 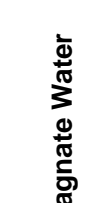 & 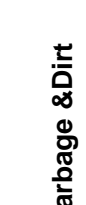 & 苛 & 离 & 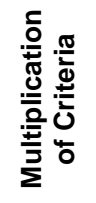 & 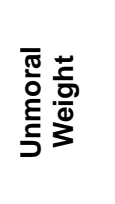 & $\frac{\frac{ \pm}{5}}{\frac{0}{0}}$ \\
\hline & & & $\dot{\omega}$ & & & & $\bar{x}$ & $X^{1 / n}$ & $\frac{\bar{L}}{\Sigma}$ \\
\hline $\begin{array}{c}\text { Garbage } \\
\text { \&Dirt }\end{array}$ & 2 & 1.42 & 1.42 & 1 & 2 & 2 & 16.23 & 1.586 & 0.249 \\
\hline $\begin{array}{c}\text { Stagnate } \\
\text { Water }\end{array}$ & 2 & 1.42 & 1 & 0.70 & 2 & 2 & 7.952 & 1.410 & $\begin{array}{c}0.22 \\
1\end{array}$ \\
\hline $\begin{array}{c}\text { Smoke \& } \\
\text { Gas }\end{array}$ & 1.42 & 1 & 00.70 & 00.70 & 1.42 & 2 & 1.976 & 1.119 & 0.176 \\
\hline Foul Odor & 1 & 0.70 & 0.50 & 0.50 & 1.42 & 2 & 0.497 & 0.890 & 00.140 \\
\hline Dust & 0.70 & 0.70 & 0.50 & 0.50 & 1 & 1 & 0.245 & 0.791 & 0.124 \\
\hline Noise & 0.50 & 0.50 & 0.50 & 0.50 & 0.50 & 2 & 0.031 & 0.561 & 0.08 \\
\hline Sum & & & & & & & & $\begin{array}{c}6.357 \\
\left(\Sigma X^{1 / n}\right)\end{array}$ & 1 \\
\hline
\end{tabular}

Reference : Calculations of Authors based on AHP model Steps of calculating of consistency ratio (CR)

1) Eigen vector matrix(AW) (saaty,1980).

$[\mathrm{A}] \star[\mathrm{B}]=\left[\begin{array}{c}1.473 \\ 1.309 \\ 1.02 \\ 0.810 \\ 0.727 \\ 0.525\end{array}\right]$

While $[\mathbf{A}]$ is pair wise comparison matrix and $[\mathbf{B}]$ is vector of weight (final weight)

2- Priority Vector(saaty,1980).

$\chi=\frac{1}{n}\left[\sum\left(\frac{\mathrm{AW}}{\mathrm{Wi}}\right)\right]=\frac{1}{6}\left[\frac{1.473}{0.24}+\frac{1.309}{0.22}+\frac{1.02}{0.17}+\frac{0.81}{0.14}+\frac{0.727}{0.12}+\frac{0.525}{0.08}\right]=5.83$

$\boldsymbol{n}$ is number of criteria, $\boldsymbol{A} \boldsymbol{W}$ is Eigen matrix, $\boldsymbol{W}_{\boldsymbol{i}}$ is weight of criteria,

3- Consistency Index (CI) (saaty,1980).

$C l=\frac{\lambda-\mathbf{n}}{\mathbf{n}-\mathbf{1}}=\frac{\mathbf{5 . 8 3 - 6}}{\mathbf{6 - 1}}=0.034$, While $\boldsymbol{n}$ is number of criteria, $\boldsymbol{\lambda}$ is priority vector

4- Consistency Ratio (CR) (saaty,1980).

$C R=\frac{C I}{R I}=\frac{0.03}{1.24}=0.02, \mathrm{Cl}$ is consistency index and $\boldsymbol{R I}$ is Random index that taken from below table

Table(6):- Random Index (RI) Table

\begin{tabular}{ccccccccccccc}
\hline $\mathbf{1 3}$ & $\mathbf{1 2}$ & $\mathbf{1 1}$ & $\mathbf{1 0}$ & $\mathbf{9}$ & $\mathbf{8}$ & $\mathbf{7}$ & $\mathbf{6}$ & $\mathbf{5}$ & $\mathbf{4}$ & $\mathbf{3}$ & $\mathbf{2}$ & $\begin{array}{c}\text { Number of } \\
\text { Criteria(n) }\end{array}$ \\
\hline 0 & 0.58 & 0.9 & 1.12 & 1.24 & 1.32 & 1.41 & 1.45 & 1.49 & 1.51 & 1.48 & 1.56 & Random Index(RI) \\
\hline \multicolumn{2}{l}{ Reference: Zebardast, 2001}
\end{tabular}

Final results of this research classify Iraqi governorates into 5 classes according to the integrating layers map by raster overlay function in ArcGIS software according to the weight of each criteria showed in the form of map and table as follows. 


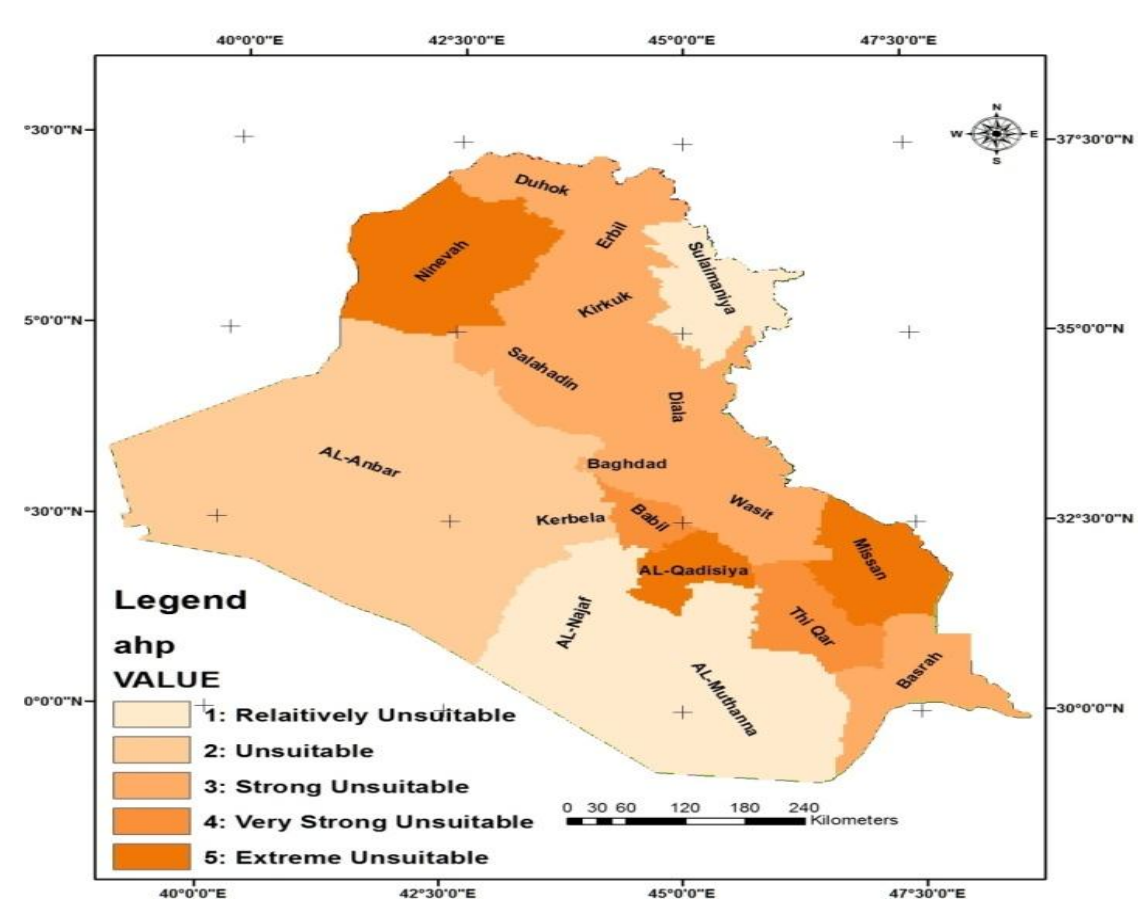

Map (8): -Final map of Environmental livability

Reference : Calculations of Authors based on AHP model and Raster Overlay in ArcGIS10.2

Table7: Classifying of Iraqi governorates based Environmental livability criteria

\begin{tabular}{llll}
\hline Class & Environmental Condition & Governorate & $\begin{array}{c}\text { Number of } \\
\text { Governorat } \\
\text { e }\end{array}$ \\
\hline 1 & Relatively Unsuitable & Al_Najaf, Al Muthanna & 2 \\
\hline 2 & Unsuitable & Sulaimaniye & 1 \\
\hline 3 & Strong Unsuitable & Basrah, Wasit, Baghdad, Diala, Salahadin, Kirkuk, Erbil, Duhok & 8 \\
\hline 4 & Very Strong Unsuitable & Babil , Thi Qar & 2 \\
\hline 5 & Extreme Unsuitable & Ninevah, Al Qadesiye, Missan & 3 \\
\hline
\end{tabular}

Reference : Calculation of Authors using AHP model and Arc GIS10.2

\section{Acknowledgements}

The authors would like to express their gratitude to all those who helped in this research

\section{REFERENCE}

-Central organization for statistic and information technology of Iraq \& Kurdistan region statistics organization\& the word bank (2012). Iraq household socio - economic survey.(www.cosit.gov.iq).

-Hankins, Katherine B(2009) The Disappearance of the State from "Livable" Urban Spaces, Antipode A Radical Journal of Geography, 41(5 ) : 845-866

-Landry, Charles, (2000) Urban Vitality: A New Source of Urban Competitiveness, Journal Vitality /
Urban Heroes,3(12):3-17.- Nel, Etienne(2005), Investigation of Pro-Poor Local Economic Development in South Africa, World BankNetherlands Partners hip Program (BNPP), Evaluating and Disseminating Experiences in Local Economic Developmen,11(2):3-11.

-Saaty TL, Peniwati K. Group decision making: drawing out and reconciling differences .Pittsburgh, Pennsylvania: RWS Publications; 2008.

http://microdata.worldbank.org/index.php/catalog/233 4/data dictionary\#page $=F 3 \&$ tab $=$ data dictionary

-Zebardast, E(2001), Applying Analytic Hierarchy Process in urban and Regional Planining, Journal of Fun Art,University of Tehran,Iran, 10 
Journal of University of Duhok., Vol. 21, No.1 (Humanities. and Social. Sciences),Pp 401-410, 2018

DOI: https://doi.org/10.26682/hjuod.2018.21.1.21 